\title{
Ye Shakoch Chilot the court of the sheikhs): A traditional institution of conflict resolution in Oromiya zone of Amhara regional state, Ethiopia
}

\author{
Meron Zeleke*
}

\section{Abstract}

Traditional institutions of conflict resolution play a very significant role in the day-to-day lives of Africans in general and Ethiopians in particular. In Ethiopia, a country that has adopted ethnic federalism as its policy, such traditional institutions help to blur political boundaries and bring people from different ethnic and regional backgrounds together. Furthermore, they serve as alternative institutions of conflict resolution in a country where the state legal system is failing to fully provide the judiciary needs of the nation. For instance, in Jille Dhmugaa district, where the research was conducted, there are only two judges for a total population of 102936 . Apart from the lack of capacity under which it suffers, the state legal system can also be criticised for a high degree of preferential treatment due to corruption, so that justice is provided only to a few. Furthermore, the ideology of the state legal system is drawn mainly from the western legal philosophy which is highly influenced by an individualistic orientation and does not fit the strong social orientation on the ground where it is being implemented. These reasons and more are raised by many as main

* Mrs Meron Zeleke is a Ph.D. candidate at the Bayreuth International Graduate School of African Studies in Germany. 


\section{Meron Zeleke}

drawbacks of the state legal system in Ethiopia. There were times in Ethiopian history when the state legal system officially incorporated elements from the traditional institutions of conflict resolution in the state courts (Carmichael 2003:122; Walker 1933:153-156). The Ethiopian constitution has, however, limited the mandate of the customary and religious institutions to private and family matters. Nevertheless, these institutions are playing a very significant role in other domains - such as criminal matters. The strong social tie existing in the community makes the significance of reconciliation, the key role of traditional institutions, indispensable.

The main questions this paper attempts to answer, on the bases of ethnographic data, are: What are the pull factors towards traditional institutions? And why do people prefer the traditional institutions vis-à-vis the state legal system?

\section{Introduction}

Sampson (1997:23-27) describes the important role played by religious institutions in conflict resolution as follows: ' $[G]$ rowing numbers of religious actors of many sorts - laypersons, individual religious leaders, denominational structures, ad hoc commissions and delegations, and interdenominational and multi-religious bodies have been involved in a range of peace building efforts ...'

Thus, the role of religious institutions is not limited to performing a spiritual mission. It goes beyond that to other domains such as conflict resolution. However, the role of religious institutions in conflict resolution is a topic that has received little academic attention - in general (Appleby 2000:1-3) and in Ethiopia in particular (Zeleke 2009b:1). The few works done on the subject can be summarised under three general categories:

- those dealing with the universal religions' role in conflict resolution and peacebuilding, (e.g. Abu-Nimer 2003; Nathan and Ayse 2000),

- those focusing on some moral values central to the universal religions like tolerance and forgiveness, and the role of such values in conflict resolution (e.g. Galtung 1965; Raymond and Peterson 2001), and 


\section{The court of the sheikhs in the Amhara regional state, Ethiopia}

- those works which highlight the two opposing dimensions of religion both as a source of conflict and as a means of resolving conflicts (e.g. Gopin 1997; Boulding 1985).

Similarly, there are very few anthropological works examining the sacred institutions of conflict resolution. Most classic works on the subject of conflict resolution give more emphasis to the customary institutions of conflict resolution and focus on mechanisms and court procedures used by these institutions, such as: mediation, arbitration and negotiation (Gluckman 1965:67; Bohannan 1989; Nader 1997; Avruch 1998). The same trend can be observed in anthropological works on conflict resolution done in Ethiopia so far (e.g. Nicolas 2006; Bassi 1992; Dejene 2002; Hamer 1972; Kelemewerik 2006; Solomon 1992).

The religious institutions of conflict resolution are considered by many to be free of the major drawbacks of the state legal system - described by many as being mainly evidence-driven and containing the possibility of false allegation and testimony. The state system is criticised as inefficient and as lacking capacity since the number of trained legal officials is disproportional to the total number of the population. Furthermore, the focus on punishment at the state court is said to lack the sense of social relationship found in the social structures of the community. Revenge is a cultural value which exists till this day in many parts of Ethiopia (Pankhurst and Getachew 2008:68). For instance, the Oromo term for killing for revenge is gumma (Huntingford 1955:63). The Amhara and the Afar call it guma (Pankhurst and Getachew 2008:68). It is clear, therefore, that the state mechanism of punishment has not managed to eradicate the long-standing norm of revenge. Experiences from different parts of Ethiopia and the case study in this paper show that what people tend to do, after passing through the penalty at the state court, is to go to the customary institutions for reconciliation and in order to control acts of revenge. Such domains are beyond the state legal system and cannot be controlled by enforcing harsh penalties. In some parts of the state, however, district justice courts work along with the customary institutions (Melaku and Wubishet 2008:107).

Focusing on this gap and on the significant roles religious institutions in Ethiopia play, the researcher's Ph.D. project deals with the topic by providing 


\section{Meron Zeleke}

an ethnographic study of a shrine - the shrine of Tiru Sina. This shrine has a weekly conflict resolution session, handling diverse cases ranging from civil to criminal matters and serving a broad geographical area. The discussion of this paper focuses on people's choices of what legal system to use, which may be termed 'forum shopping'. I will examine which factors pull or draw people to bring their cases to the shrine-based judiciary instead of to the state court.

This paper has three parts. The first gives a brief description of the shrine and the court of the sheikhs in order to give readers an overview of the institution under study. The second part deals with the diverse nature of cases handled by the court of the sheikhs. Part three is where the main argument around factors affecting the forum shopping process, will be discussed at length.

\section{An overview of the shrine of Tiru Sina and the Shakoch Chilot (court of the sheikhs) at the shrine.}

\subsection{The establishment of the shrine}

The shrine of Tiru Sina is located in Oromiya zone of Amhara Regional State, in Jille Dhumugaa district, at Arba Wayu kebele (peasant association). The shrine was founded by a sheikh named sheikh Siraj Mohammed Awel, a famous sheikh from Yejju born around 1885 at a place called Dana in Yejju. Sheikh Siraj has done his religious studies in different famous Islamic schools in Wollo and Shewa (in north central Ethiopia). He has studied in Shonke and Gata in Wollo and in Aliyu Amba in north Shewa. He established other shrines in Mekdessa, Chafa Robit, Jubaruhman, Chiri and Karakore. The shrine of Tiru Sina was established under an Islamic framework (Zeleke 2009a:1).

As the very name of the institution under study, Ye Shakoch Madad (the abode of the sheikhs) suggests, the shrine is run by the sheikhs who are the founders and leaders of the shrine. This institution of Ye Shakoch Madad has a regular court of sheikhs called Ye Shakoch Chilot.

The shrine of Tiru Sina was established around 1949. Before the establishment of the shrine at Tiru Sina the area was one of the hot spots for ethnic conflict between the Oromo and the Amhara. According to informants who were 


\section{The court of the sheikhs in the Amhara regional state, Ethiopia}

residents of the area during the time of the conflict, the conflicting parties were the Oromo of the wereda, Amharas from the neighbouring district of north Shewa and the Saddacha (the assimilated migrant Oromos from different parts of South Wollo). The conflicts were caused by land issues between these different groups. Governors of the area have tried to end the conflicts, but failed. Sheikh Siraj, who was on the verge of getting a reputation for his extraordinary spiritual power of performing miracles and healing, managed to convince both parties to come to peaceful terms. This incident has helped the sheikh to win a reputation both from emperor Haile Selassie and of the community at large. This has also helped him to get official support and build a close relationship with Emperor Haile Selassie, who was thankful to the sheikh who managed to end the conflict. ${ }^{1}$ This relationship with the emperor helped him to strengthen his shrine at Tiru Sina and obtain ownership of land in different parts of the zone and in different areas of today's north Shewa. These rewards for his successful conflict resolution helped him to accumulate power. Sheikh Siraj passed away in 1972. Upon his death, the shrine stopped serving the purpose of Islamic education, but what continued on a regular base were the weekly conflict resolution sessions, the weekly wadaja (group prayer), the zar hadra (sessions of prayer, chants, singing, and dancing by a group of possessed individuals), healing rituals, and the biannual pilgrimage to the shrine.

\subsection{The court of the sheikhs}

On account of the successful ethnic conflict resolution of the 1930s, the shrine of Tiru Sina began to provide the service of conflict resolution. The sheikh obtained legal recognition from the local and central government officials and was encouraged to carry out the role of conflict resolution. There are two different accounts of how he has got involved in the weekly conflict resolution. There are those who attribute the initiation of his weekly court to Emperor Haile Selassie, who was impressed by sheikh Siraj's successful peace deal between the ethnic groups in conflict. Others provide a religious explanation linking his

1 Both primary data obtained from interviews conducted and the secondary data from the archives in the two shrines of Tiru Sina and Mekdessa, which included letters sheikh Siraj exchanged with the emperor and government officials, provide evidence of this good relationship. 


\section{Meron Zeleke}

reconciliation activity with 'his call' and a gift he got from Allah. At any rate, the emperor gave sheikh Siraj an official seal which he put onto the contract he made between the disputing parties after the reconciliation. The use of the seal was not limited to this domain, however, as can be seen when examining the archives at the shrine. ${ }^{2}$ Such shrines, located in different parts of north central Ethiopia, have played an important role as centres of Islamic learning in the country (Hussein 2001:1-5).

Unlike other customary institutions of conflict resolution in Ethiopia, which take place on an ad hoc basis (Pankhurst and Getachew 2008:52), the court of the sheikh is held regularly. There is a weekly court hearing at the shrine every Monday from 9 a.m. until late afternoon - depending on the number and type of cases. There are three sheikhs who are in charge of leading the court. One of the sheikhs sitting at the court is the grandson of sheikh Siraj while two are the deresas (students) of sheikh Siraj. The hearings are held under a big Podocarpus tree.

The average number of cases handled at the court range from ten to twelve per week, which is an average of forty to fifty cases in a month. There was a total of forty eight cases presented at the court of the sheikhs in the month of March, 2009. Some of the case materials presented below have been taken from these cases. This number is greater by far than the number of cases handled by the state mahbarawi fird bet (the social court) which dealt with only seven cases in the two months of February and March. ${ }^{3}$

In addition to the greater quantity of cases handled by the court of the sheikhs, it can also be said that these cases may acquire an extra quality. The three main elements of the court of the sheikhs which involve the spiritual dimension are: blessing, cursing and oath taking.

2 The archival materials obtained from the shrine of Mekdessa show that this seal was also used by the sheikhs for the letters he exchanged with friends, family and others.

3 The researcher's field notes of an interview with the head of the Arba Wayu kebele, 10 June 2009, at Ataye. 


\section{Different types of conflicts handled by the court of the sheikhs}

In the study area there are different institutions of conflict resolution. This is therefore an instance which can be described as legal pluralism. ${ }^{4}$ Similar instances of legal pluralism have been observed elsewhere in Africa like in Guinea Bissau (Klute and Emballo 2006:1-3).

In the constitution, customary and religious institutions were given a constitutional right to handle personal and family matters if the disputants gave consent to get jurisdiction by these institutions. According to the 1995 constitution, Article 34 (5), 'This Constitution shall not preclude the adjudication of disputes relating to personal and family laws in accordance with religious or customary laws, with the consent of the parties to the dispute. Particulars shall be determined by law'.

The constitution also mentions that there is a possibility of giving legal recognition to such institutions, as stated in article 78 (5): 'Pursuant to subarticle 5 of Article 34 the House of Peoples' Representatives and State Councils can establish or give official recognition to religious and customary courts. Religious and customary courts that had state recognition and functioned prior to the adoption of the Constitution shall be organized on the basis of recognition accorded to them by this Constitution'.

As the case studies of such customary institutions of dispute resolution from different parts of Ethiopia discussed in a book by Pankhurst and Getachew (2008:8) clearly demonstrate, these institutions operate beyond the domains of family and personal matters mentioned in Article 34 (5) of the constitution. The court of the sheikhs handles conflicts of various nature, ranging from minor disputes between individuals to criminal cases like homicide and theft, as well as inter-ethnic conflicts. In May 2009, the sheikhs dealt with a conflict between two ethnic groups which arose due to a dispute over a grazing land between the neighbouring Amharas from a village called Kara Logoma in Ephrata ina

4 Legal anthropologists understand law as a cognitive order resulting from social structures such as ethnic groups, states and villages - so in any situation there is the possibility that various kinds of law might be used. 


\section{Meron Zeleke}

Gidim district and pastoralist Oromos from Arba Wayu kebele. Dealing with such inter-ethnic conflicts is an exclusive mandate of the federal court. Thus this case clearly showed the fact that the court of the sheikhs operates beyond the mandates given to customary institutions of conflict resolution as stated in article 34 (5) above. This was done to the extent of stepping into a case of ethnic conflict, which is described to be an entity of the federal government and not even of the regional and district courts. The shrine also serves a wide geographical area. Though the shrine is located in Oromiya zone of Amhara regional state, most clients of the shrine are Amharas from different districts in north Shewa zone, the majority of whom come from Ephrata ina Gidim, and Ansokiya Gamza districts of north Shewa zone.

There were cases coming from as far as Addis Ababa $(300 \mathrm{kms}$ south of the shrine), Arba Minch (725 kms south of the shrine) and diasporas in the Middle East. It is an institution whose service crosses ethnic and regional boundaries. Drawing from the fact that the court of the sheikhs operates beyond its 'legal mandate' and the fact that people bring in different cases from different geographical areas, it might appear necessary to raise the question: Why is it that people tend to prefer Tiru Sina to the state institution? Part three and the remaining part of the paper will present ethnographic data in order to deal in detail with this question.

\section{Opting for the court of the sheikhs vis-à-vis the state legal system}

In order to see what factors accounted for making the legal choice and whether people are making rational choices, it is important to observe the considerations from three perspectives. First, the stated reason for choosing the institution instead of the state legal system. Second, the way cases have been handled at the institution. And third, the extent to which the outcomes were related to the expectations of a party and provided satisfaction afterwards.

As the findings of the research show, the reasons why people tend to bring their cases to the court of the sheikhs can be grouped under four major categories: 


\section{The court of the sheikhs in the Amhara regional state, Ethiopia}

1. The sheikhs' court focus on reconciliation and re-establishing social harmony, which the state legal systems lack

2. The clients' suspicion about the effectivity and trustworthiness of the state legal system and its mechanisms of conflict resolution

3. The state courts' non-recognition of some deep-rooted cultural elements found in the community whereas the court of the sheikhs is culturally embedded

4. The procedural flexibility of the court of the sheikhs

Each category will be dealt with in detail by presenting ethnographic examples from the court of the sheikhs. It is important to note that this categorisation is not fully discrete, as it can be seen from the cases to be discussed below that while some of them are mentioned under one category, they also fit another.

\subsection{Category 1: Focus of the sheikhs' court on reconciliation and re-establishing social harmony}

The issue of reconciliation is described as being at the centre of dispute settlement by customary institutions, which is not the case in the state legal system. The government's justice system does not erase from disputants' minds that there may have been a long-running feud between them (Pankhurst and Getachew 2008:107).

The court of the sheikhs is also keen to avoid the sense of grudges (tit for tat). In a way the institution also serves as a damage control institution. The case materials labelled 1-2 below best explain the issue of reconciliation and establishing social harmony.

\section{Case 1: A murderer's family seeking reconciliation with the family of the murdered}

Ali killed Abdu in December 2008, suspecting him of committing adultery with his wife. Ali and five friends of his died in Bassaso (Somaliland) while trying to travel to the Middle East by boat. The news reached the family of Ali by two young men who survived the accident and made it to their final destination, Yemen. The police gave up the case when they got this information about Ali's 


\section{Meron Zeleke}

death. However Ali's father brought the case to the court of the sheikhs on 23 February 2009 in order to ask the family of the victim for reconciliation. The sheikhs sent a message to the house of Nuru (Abdu's father) to inform him about the case and to call him to the shrine on 28 February to discuss the matter with the respective sheikhs running the weekly court. Upon his arrival the sheikhs briefed him about the request from the side of Ali. The sheikhs were blaming Ali and his father and they informed Nuru that God had punished Ali for the crime he committed and that his family should give up the grudge, saying: ya iujun allh ina sheikoch satatwita inanta gomiyachihun anisu (Allah has punished the criminal; thus there is no need to take revenge). He was emotional and it took them about an hour to convince him to accept their proposal of reconciliation. They convinced him to come to terms with the other side. Finally, they agreed that he would bring the young ones from his side to the court of the sheikhs on the next Monday (2 March).

Nuru arrived with 11 young men who are related to him. Ali's father came with 15 of his relatives. The sheikhs started the session by blessing both parties, especially the victims, for their willingness to come to the court of the sheikhs. During most of the discussion they focused on blaming Ali and appreciating the chawanat (decency) of the victim's side for not taking revenge so far. Ali's father and his relatives shared this idea with the sheikhs. They appreciated the victims' side for not hurting them or taking any measure so far. Finally they arrived at the conclusion of the need for compensation, as Abdu (the victim) was an active breadwinner to his family.

The sheikhs decided that Ali's side should pay 5000 birr (equivalent to US\$ 350) compensation. They all agreed to the proposal. This agreement was ratified by a ritual of shaking hands while holding a carpet between the two parties as a cover to avoid eye-to-eye contact. Both parties where made to hold a spear and bury it in the ground, a ritual symbolising the end of hostility and the establishing of peace. The burying of the spear symbolises ending the enmity, and the sheikhs' holding of the spear highlights that anyone in the two parties who attempts to fight in the future will be cursed by the sheikhs. The use of the spear in reconciliation is a common phenomenon among many Ethiopian communities, 


\section{The court of the sheikhs in the Amhara regional state, Ethiopia}

such as the Nuer (Dereje 2008:142), the Arbore (Pankhurst 2005:1), and the Gumuz (Zeleke 2010).

When Ali's father was asked why he brought the case to the Shakoch Chilot, especially after his son had passed away and after the government had dropped the case, he answered:

The state only chases the suspected one. When they came to know that he died, the case also died for them (the state). But it is more than that. They (the victims) also have men on their side (to take revenge). Those men will not stop their manhood (sense of retaliation). We believe that the sheikhs are the ones who can let them forget the matter. That was why we appealed to them.

From his words and from this case in general one can see four points of central importance. First, the fact that the concept of dhirumaa (manhood) means the obligation to revenge and safeguard one's own or one's kin's pride. Killing a member of one's kin means challenging the dhirumaa of the whole group. One then wants to prove his manhood by doing the same (an eye for an eye approach).

Second, one can see that the state holds to account only the accused and that there is no point in the legal system which accuses close relatives of him/her. In the community, however, the close social ties on the ground show that members who are close kin to the accused are held equally guilty, especially when the crime is related to blood (killing). The institution of the sheikhs is aware of such cultural elements and they operate according to this cultural framework. In such a complex cultural setup the role of the state is very minimal. Thus people tend to bring their cases to the institution which they think is considerate of such important cultural elements.

Third, the statement, The sheikhs stand for those who are alive, means that they work towards avoiding further grudge and establishing compensation where necessary. In this case, the father got compensation in consideration of the productive age of the deceased son who was a breadwinner in the family.

Finally, both parties took an oath confirming that they will not resume the conflict and will abstain from reprisals. One of the two judges from the district 


\section{Meron Zeleke}

state court has been interviewed to learn about the perspective of the government legal officials on this point of avoiding further damage and on the case material presented above. The judge confirmed that the government legal system deals only with the accused. He expressed this with the phrase wanjal aywarasim: 'Crime isn't inheritable'. So, the judge mentioned that by penalising the accused, the state legal system believes it is controlling elements of revenge as people may learn from the penalty to be incurred by the accused. From his words, we can see that the government legal system operates under an individualistic approach. As the legal system is adopted from a western operational logic it draws most of its formalities from this perspective. Kohlhagan (2008:77) has mentioned this point saying, 'Although the country knew a great variety of local legal traditions, the new legislation was almost exclusively inspired by western conceptions of law? But facts on the ground, like the case material presented above, highlight that the social structure and context is quite different from the western 'individualistic' social structure. Penalty is not going to end the enmity and the cultural values of guma (revenge) or control the damages that arise due to the cultural structure. The more effective control mechanisms are the customary institutions which focus on reconciliation through compensation and symbolic penalty.

\section{Case 2: A freed prisoner seeking reconciliation at the court of the sheikhs after serving his term}

Ato (Mr) Genanaw was accused of attempted murder, for shooting at Ato Birhanu, and was sentenced to an imprisonment of six months. Upon his release, he went with three elders to Tiru Sina to take a paper to call Ato Birhanu to attend the Shakoch Chilot held on 2 March 2009.

On Birhanu's arrival on the day, one of the sheikhs explained to him why he was called to the Chilot and urged him to accept the reconciliation request proposed by Ato Genanaw who had regretted his act. The sheikhs informed Birhanu about the value of forgiveness.

As in the first case above, the sheikhs appreciated him for not taking any actions to hurt the family of Ato Genanaw and he was blessed for that. Finally, those men were made to kiss each other (mazayarar) and eat food from the masob (basket 


\section{The court of the sheikhs in the Amhara regional state, Ethiopia}

made of straw) which Ato Genanaw brought. This ritual symbolised the message of ending enmity and eating from the same plate (sharing).

As it was Ato Genanaw who brought the case to the sheikhs, he was asked why he needed to bring it as he has been imprisoned and 'penalised' for the crime he committed. As in the first case Ato Genanaw also highlighted the issue of social coexistence, saying:

My imprisonment will not erase my wrongdoing and Ato Birhanu's hurt from his mind. He (Ato Birhanu) might say one day, let me kill the person who intended to kill me! He is a man and that is how men do it! That is why I came to their madad (referring to his appeal for reconciliation through the sheikhs).

The idea of manhood as a euphemistic metaphor for the norm of taking revenge can be used in a cross-cutting way among ethnic and religious groups where this norm exists. The issue of dhirumaa as it appeared from the Oromo Muslim informant mentioned above clearly shows that it is a cultural code that cuts across ethnic and religious background. This cultural code is based on the logic of an eye for an eye, which is called wandinat among the Amhara, but also exists across ethnic groups.

The institution of the state always favours the victim but that does not mean that it ends the elements of revenge. Thus, people tend to take their cases to such institutions such as the court of the sheikhs which are controlling further damages that might have arisen from such common cultural codes. They operate under the cultural norms of the community.

As case studies 1 and 2 clearly show, clients of the court of the sheikhs mention that the state institution's focus on penalty will not promote social coexistence, and thus they are challenging the operational logic of the state legal system which focuses on penalty and also on individual accountability.

\subsection{Category 2: Doubt about the effectivity and trustworthiness of the state legal system}

Many people coming to the court of the sheikhs raise points which highlight their dissatisfaction with the state court's mechanisms for dealing with different 


\section{Meron Zeleke}

cases, the expenses incurred, the long timespan to finalise a case, issues of corruption, and over-emphasis given to evidence.

The case materials presented below demonstrate some of the factors which push people away from the state legal system and pull them towards the court of the sheikhs. However the analysis of the materials at hand and the discussion with the state legal officials show that some of the factors raised here are also related to the lack of information people have about the state legal system.

\section{Case 3: A house rent case taken to the court of the sheikhs}

Waizero (Mrs) Almaz, a woman in her late 60s who lives in Kara Kore town, accused a teacher, who used to rent her house, for failing to pay her 30 birr (equivalent to US\$2.50) monthly house rent. He left her house without paying the rent. She brought the case to the court of the sheikhs. When being questioned by the sheikhs about the accusations, the man admitted and apologised. The sheikhs made him to pay it on the spot and asked Waizero Almaz to forgive him.

The woman was asked why she did not report the matter to the police. She came up with three explanations. One was the economic factor: that the cost to be incurred at the state legal institution could be far more than the 30 birr. The second reason was that a state court handling such contractual issues always asks for evidence or verification for the accusation. Thirdly, she also mentioned that the chances of winning a case at the state court for somebody like her who is illiterate are minimal compared to those of her client who is educated and mawchiya magbiywin yawikal (who knows the ins and outs of the system).

Her answer is a good example of a lack of information about the legal rights of individuals and the procedures and mechanisms at the state court. With regard to the economic factor, the state legal system has organised a system whereby the kebele social court concerned can verify the income of individuals and give those with low income a support letter which will allow them to get a legal service with an arrangement of long-term pay back. With regard to the issue of evidence raised by Waizero Almaz, the officials at the district court explained that the civil cases which require written contractual evidence are those matters which 


\section{The court of the sheikhs in the Amhara regional state, Ethiopia}

go beyond 500 birr, so that in this specific case no written evidence would have been required by the state court.

It can be seen from this case and others that there is an information gap regarding the legal rights of individuals as stated in the constitution and as upheld by the state legal system. Findings of the discussions with the legal officials in Senbate (the district's capital) indicate that the mechanism adopted by the Aqabe hig (public prosecutor) called Niqate Hig (legal awareness) aims at informing people of some basic legal services and rights of individuals. However, this strategy adopted by the public prosecutor takes place only once in a year when officials go to kebeles in turn and try to educate the community. On the basis of the latest census, the total population of the district is 102 936, but for the whole district there are only two judges and three public prosecutors.

\subsection{Category 3: The state legal system's non-recognition of some cultural elements of the community}

As mentioned above, the categories are not discrete and some of the cases discussed above might also fit into this category. The cases falling under this category show that the state legal system does not handle some cases which are said to be irrational or not based on logic. Cases 1 and 2 above clearly show how such cultural elements as wandinat, dhirumaa (manhood) are common in the community and how the state institutions fail to address the cultural elements by underplaying the need for reconciliation and emphasising penalty as a control mechanism.

\section{Case 4: A case referred to the court of the sheikhs by a Bala Wuqabi (spirit medium)}

Abarash, a woman from Chafa Robit town, was accused by Adanech for causing her misfortune by tying the siqilat. Pankhurst and Getachew (2008:xviii) explain this custom as follows: 'placing a cloth symbol on a tree to make the opponent come to the "court" and bind him/her till the resolution of the conflict'.

They had a disagreement five years before over land and the state court decided to give the land to Adanech. After the decision had been reached, Abarash came to the court of the shrine of Tiru Sina and had the siqilat tied. Since then, Adanech's 


\section{Meron Zeleke}

daughter died, her other daughter had a miscarriage, and both Adanech and her son became seriously ill. She went to a Bala Wuqabi (spirit medium) to find out what was causing her and her family so many misfortunes. The Bala Wuqabi told her that her neighbour with whom she fought over land had tied the siqilat at Tiru Sina and it is only when that woman goes and unties the siqilat that she and her family will be safe of further misfortunes.

Abarash was seriously ill and the sheikhs approved that her daughter Ababa could represent her mother at the court of the sheikhs. According to Ababa, Abarash seemed to be conscious of why she was called to the Shakoch Chilot. When Ababa was asked about her mother's reason, she said that her mother had admitted that the reason was ilih (grudge). When Adanech was asked why, after she had been to the spirit medium, she brought the case to Tiru Sina and did not take it to the court of the state, she explained:

The state officials do not get this right. They only deal with something observable, but there are so many things in life which are non-visible and which only those who have karama (the power to perform miracles) can see. They (the state legal officials) might ask the Bala Wuqabi: Have you seen her (Abarash) doing it? They do not understand it at all!

Unlike the cases which question the effectiveness of the state legal system and the trustworthiness of the particular institution, presented under category two above, the cases involving cultural elements are society-specific. There are the cultural beliefs and practices that are specific to some cultures. Social value, therefore, has to be taken seriously. With regard to cases where people bring health-related problems to the Bala Wuqabi, Aspen (2001:194) states that 'an underlying motive of clients may be the suspicion that there are identifiable supernatural powers that cause the afflictions and [the trust] that the weqabi may know the appropriate treatment.... Aspen (2001:194) further explains that the society regards the causes of misfortune or sickness as being embedded in the society. As long as the cause of the misfortune is believed to be in the society, they also believe that the solution is to be found in such institutions that exist within the society. They are also conscious of the fact that a government 


\section{The court of the sheikhs in the Amhara regional state, Ethiopia}

institution does not recognise such problems as a problem at all and rather describes them as 'yahuala ker bahil' (backward cultural practices).

For the domains where the state institution does not operate, people prefer to bring their cases to those institutions like the court of the sheikhs - that are conscious of the cultural setting in which they are operating. In order to make themselves relevant, these institutions deal with such problems, as the case material presented above and the forthcoming case clearly highlight.

However, the issue of looking for verification that such problems have been caused by afziz adengiz (sorcery) causes state institutions to look for evidence to label a matter under this category. According to an informant from the state court, a case, if verified with a laboratory test or by an eye witness account, might indeed be considered as a crime.

\section{Case 5: A case about a lent sickle}

Tayach, a woman running a mini-bar in Kara Kore town, lent a sickle to a neighbour of hers, Ato Kabada. However, Kabada returned another sickle to Tayach. She accused him at the court of the sheikhs. She said that the sickle he gave her back was a new and expensive one while the one she lent him was an old one that had a mark.

At this point it was quite surprising that she found it necessary to travel all the way to Tiru Sina if she got the new sickle instead of the old one. In other words, why did she accuse him of stealing while he has paid it back? When Tayach was asked why she brought the case to the court of the sheikhs instead of reporting it to the state legal authorities, she explained how her fear of affliction would be underplayed in the state court:

Had I taken the case to the state legal institution, they would have told him to pay me back but what I want back is my own sickle. If I insist on accepting that, they would say a sickle is a sickle anyway! But it is more than that. My own sickle might be used against me to cause me harm. (She expressed it using a metaphor comparing the seriousness of affliction with the damage that can be caused by the sharp edge of a knife or sickle.) They (those at the state court) do not understand these things! 


\section{Meron Zeleke}

Kabada agreed to look for the lost sickle and return it to Tayach. After three months they came to the court of the sheikhs. Kabada brought the sickle which he found at his farm in the harvest season and returned it to Tayach. She was asked to forgive him and they were advised to maintain their relationship. Tayach seems to have been right in the remark she made about the state legal system.

According to an informant from the district court, this case is a civil and individual matter. She gave him her sickle willingly and he changed it but did not steal it or cheat her. The district judge also said that this case is not a criminal case to be addressed by the state court, but a civil matter. Had she brought the case to the court, Kabada would have been asked to pay the sickle back.

\subsection{Category 4: The procedural informality and convenience of the court of the sheikhs}

The issues discussed under this section mostly deal with the question of how the sheikhs deal with different cases and how both the sheikhs and the clients arrive at a compromise. Unlike studies describing court procedures, the methodology adopted was focused on the pull factors of the non-state institutions of conflict resolution, which influenced people to present their cases at the court of the sheikhs.

Factors such as the possibility of negotiation at the court of the sheikhs, and the informality of this court that gives time to clients to present their cases and defend accusations, can be identified as pull factors.

One of the reasons most informants have mentioned was that at the state court they need to be careful with what they say and how they act. Waizero Almaz (case 3 above) narrated her encounter at the state court in Ataye where she went as a witness as follows:

There (at the state court), if you sneeze, that will be counted as disrespect. You cannot speak out of your turn, and even when your turn comes they stop you after a while. They bombard you with questions. It is a trouble!!! Confusing a client is all they are up to!

In some of the cases handled above, and also at other occasions, clients felt that the sheikhs were not attentive and asked them to listen attentively to what they 


\section{The court of the sheikhs in the Amhara regional state, Ethiopia}

were saying. There were cases where clients used the proverb wag ba ayin yigabal (it is good to be observed while speaking) to draw the attention of the sheikhs to what they were emphasising.

The informality of the court of the sheikhs also leaves some space to the clients to shape the decision-making process and turn the outcome of the decision to their best interest. An ethnographic example best explaining this point is the case of the sickle presented above. In handling this case, the sheikhs seemed to have underestimated the affliction caused by the lost sickle. Unlike the state system, which considers such a claim as irrational, the sheikhs - while objecting to this case - were indeed centring on the spiritual dimension. They realised that by bringing the case to the court of the sheikhs, Tayach has minimised the risk of affliction as a result of sorcery. However, Tayach argued against this point by drawing on some scriptural examples from the bible which showed that Satan has power to cause misfortunes. The sheikhs found this irresistible and had to agree with her accusation. They ordered the offender strictly to bring the sickle back and to give up any plans he might have of harming her. She also influenced the decision by insisting on a confirmation that he had not yet used the sickle for digimit. For that the sheikhs made him swear an oath.

\section{Conclusion}

Religious institutions of conflict resolution are playing a very significant role in resolving conflict. In a state which cannot provide justice at the grassroots level due to lack of capacity - resulting from a lack of legal officials and funds, as well as other reasons - the role of the traditional institutions is very significant. This inefficiency of the state legal systems makes alternative institutions of conflict resolution indispensable. The traditional institutions in the country have responded to this urgent need and are covering a wide geographical area.

They handle cases of diverse nature ranging from civil to criminal matters. Although article 34 (5) of the constitution of the Federal Democratic Republic of Ethiopia limits the right of the customary and religious institutions to handle only private and family matters, they operate in more domains than 


\section{Meron Zeleke}

they are mandated to. Everyday experience in Ethiopia clearly shows that such institutions are indeed handling criminal cases, including cases of homicide.

The push factors, away from the state legal system with its limited capacity and western, individualistic operational logic, do not only cause a lack of trust in the state system, but are at the same time pull factors towards the religious institutions of conflict resolution. These institutions use different procedures such as oathtaking, swearing, blessing and cursing, which are of a transcendental nature. The society has more moral ties with the religious institutions of conflict resolution than with the state legal system where one can get away with committing a crime and denying it. The verification at the faith-based institutions of conflict resolution is entrusted to the third party who is believed to be transcendental (God).

The four main reasons why people turn to the sheikhs' court are:

- the sheikhs' court's focus on re-establishing social harmony and reconciliation,

- the suspicion about the effectivity and trustworthiness of the state legal system and its mechanisms,

- the state courts' non-recognition of some deep-rooted cultural elements found in the community, and

- the procedural flexibility of the sheikhs' court.

The first and the fourth of these reasons can be categorised as institutional strengths of the court of the sheikhs vis-à-vis the state legal system, while the second and the third point to shortcomings of the state legal system.

Besides these main reasons, others are the long time-span taken at a state court for processing a case, the expenses incurred at the state court, the undue emphasis on evidence, and the possibility of corruption.

Informants highlight the element of reconciliation at the court of the sheikhs as a major pull factor. The state legal system which operates under the western legal system's logic of penalising a guilty party lacks the ability of securing sustainable peace and allowing the parties to reach reconciliation. The social value of revenge, euphemistically called 'manhood', is one of the important cultural aspects which the court of the sheikhs addresses more than the state 


\section{The court of the sheikhs in the Amhara regional state, Ethiopia}

legal system. After completing a trial at the state court, people still tend to bring their cases to the court of the sheikhs to reach reconciliation. The strong social ties in the study area and the strong social structure of kinship strengthen the social accountability of the social group. On the contrary, the state holds only the criminal accountable for what he/she did.

\section{Sources}

Abu-Nimer, Muhhamed 2003. Nonviolence and peace building in Islam: Theory and practice. Gainesville FL, University Press of Florida)

Appleby, Scott 2000. The ambivalence of the sacred: Religion, violence and reconciliation. Lanham MD, Rowman and Littlefield.

Aspen, Harald 2001. Amhara traditions of knowledge. Spirit mediums and their clients. Wiesbaden, Harrassowitz Verlag

Avruch, Kevin 1998. Culture and conflict resolution. Washington D.C., University for Peace Press.

Bassi, Marco 1992. Institutional forgiveness in Borana assemblies. Sociology Ethnology Bulletin, 1 (2), pp. 50-54.

Bohannan, Paul 1989. Justice and judgment among the Tiv. Long Grove IL, Waveland Press.

Boulding, Elise 1985. Two cultures of religion as obstacles to peace. Paper presented the thirty second annual conference of the Institute on Religion in an Age of Science, on the theme: Can scientific understanding of religion clarify the route to world peace? Star Island, New Hampshire, 27 July to 3 August 1985.

Carmichael, Tim 2003. Afarsata. In: Uhlig, Siegbert ed. Encyclopaedia Aethiopica, Vol. 1. Wiesbaden; Harrassowitz Verlag.

Dejene, Gemechu 2002. Some aspects of conflict and conflict resolution among the Waliso Oromo of eastern Meccha with a particular emphasis on Guma. M.A. thesis in Social Anthropology, Addis Ababa University.

Dereje, Feyissa 2008. Customary dispute resolution in Gambella region: The case of the Nuer. In: Pankhurst and Getachew, pp. 133-155.

Galtung, Johan 1965. On the meaning of non violence. Journal of Peace Research 2 (3), pp. 228-256.

Gluckman, Max 1965. The ideas in Barotse jurisprudence. Manchester, Manchester University Press.

Gopin, Marc 1997. Religion violence and conflict resolution. Peace and change, 22 (1), pp. 1-31.

Hamer, John 1972. Dispute settlement and sanctity: An Ethiopian example. Anthropological quarterly, 45 (3), pp. 232-247. 


\section{Meron Zeleke}

Huntingford, George 1955. The Galla of Ethiopia: The kingdoms of Kafa and Janajero. London, International African Institute.

Hussein, Ahmed 2001. Islam in the nineteenth-century Wollo, Ethiopia: Revival, reform and reaction. Leiden, Brill.

Kohlhagan, Dominick 2008. State law in Sub-Saharan Africa. In: Pankhurst and Getachew, pp. 77-93.

Kelemewerik, Tafere 2006. Indigenous institutions of conflict resolution among the Abbala of Afar on North east Ethiopia. Social Anthropology dissertation series, No. 11. Addis Ababa.

Klute, George and Idrissa Emballo 2006. Local strategies of conflict resolution in Guinea Bissau. Project proposal in Legal Anthropology. Recht in Afrika, No. 2, pp. 253-272.

Melaku, Abate and Shieferaw Wubishet 2008. Customary dispute resolution in Amhara region: The case of Wofa legesse in northern Shewa. In: Pankhurst and Getachew, pp. 107-123.

Nader, Laura 1997. Law in culture and society. Berkeley CA, University of California Press.

Nathan, Funk and Kadyfic Ayse eds. 2000. Peace and conflict resolution in Islam: Percepts ad practices. New York, New York University Press.

Nicolas, Andrea 2006. From process to procedures. Elders' mediation and formality in eastern Shewa. Ph.D. dissertation, Institute of Ethnology, Free University, Berlin.

Pankhurst, Alula 2005. A peace ceremony in Arbore. In: Strecker, I. ed. The perils of face: Essays on cultural contact, respect and self-esteem in southern Ethiopia. Münster, LIT Verlag.

Pankhurst, Alula and Assefa Getachew eds. 2008. Grass-roots justice in Ethiopia: The contribution of customary dispute resolution. Addis Ababa, Centre francais d'études ethiopiennes.

Raymond, Helmick and Rodney Peterson eds. 2001. Forgiveness and reconciliation: Religion, public policy and conflict transformation. Philadelphia, Templeton Foundation Press.

Sampson, Cynthia 1997. Religion and peacebuilding. In: Zartman, I. William. and J. Lewis Rasmussen eds. Peacemaking in international conflict: Methods and techniques. Washington D.C.: United States Institute of Peace Research. Pp. 273-316.

Solomon, Gebre 1992. Conflict resolution in traditional Amhara society. Sociology Ethnology Bulletin, 1 (2), pp. 55-60.

Walker, Charles 1933. The Abyssinian at home. London, The Sheldon Press.

Zeleke, Meron 2009a. The shrine of Tiru Sina and its role in peace building and development. Paper presented at a conference on The role of religion in securing society, Hilton Hotel, Addis Ababa.

Zeleke, Meron 2009b. The case of the Islamic shrine of Tiru Sina: Religion and conflict resolution. Paper presented at an international conference of Ethiopian Studies, Addis Ababa.

Zeleke, Meron 2010. The mother and the breadwinner: The Socio economic role and status of the Gumuz women. Münster, LIT Verlag. 